\title{
Kirjaoskuse arendamine eesti keele ja kirjanduse õpetajate vaatevinklist: sillad ja kuristikud teooria ja praktika vahel
}

\author{
Merilin Aruvee $^{\mathrm{a} 1}$, Helin Puksand ${ }^{\mathrm{b}}$ \\ a Tallinna Ülikooli humanitaarteaduste instituut \\ ${ }^{b}$ Tartu Ülikooli eesti ja üldkeeleteaduse instituut
}

\begin{abstract}
Annotatsioon
Inimesed suhtlevad tekstide vahendusel ja nii on tekstikesksel emakeeleõpetusel oluline roll kirjaoskuse saavutamises. Kirjaoskuse kui üldpädevuse peab aga tagama kool tervikuna. Uurimuse probleemina selgitatakse, kuidas eesti keele ja kirjanduse õpetaja teksti vastuvõttu õpetab ning tekste süsteemse keeleõpetusega seob, et sedamööda leida võimalusi kirjaoskuse koostöiseks õpetamiseks aine- ja keeleõppe lõimingus. Eesmärk on õpetajate kogemuse alusel osutada eesti keele ja kirjanduse didaktika arenguvõimalustele ning kirjeldada eesti keele rolli suhtluspädevuse õpetamisel. Põhistatud uurimusest järeldub, et tekstikeskne keeleõpetus jääb kirjaoskuse arendamisel pigem kõrvale, uut kirjaoskust arendatakse tagasihoidlikult. Samas ilmneb tekstivalikute kaudu emakeeleõpetuse interdistsiplinaarsus. Et arendada kirjaoskuse koostöise õpetamise metoodikat ja tekstikeskset keeleõpetust, pakutakse artiklis ideid nii ülikooli eesti keele ainedidaktika arendamiseks kui ka kirjaoskusõpetuse lõimimiseks õpetajakoolitusse.
\end{abstract}

Võtmesõnad: uus kirjaoskus, tekstikeskne keeleõpetus, metalingvistiline teadlikkus, LAK-õpe

\section{Sissejuhatus}

Kirjaoskus kui üldpädevus tagatakse Eestis kõigi kooliainete õpetamise kaudu (vt Aruvee, 2017). Riiklikus õppekavas nimetatakse kirjaoskust suhtluspädevuseks, mis tähendab tekstitoimingute valdamist kõnes ja kirjas, sobivate keelevahendite valikut suhtluses ning eri liiki ja laadi tekstide eesmärgistatud

Humanitaarteaduste instituut, Tallinna Ülikool, Narva mnt 25, 10120 Tallinn; merilin.aruvee@tlu.ee 
lugemist (vt PRÕK, 2011, $\$ 4$ ). Suhtluspädevus haakub peaaegu täiel määral eesti keele ja kirjanduse ainevaldkonna eesmärkidega, mis teeb eesti keelest justkui metaaine, millega toetatakse teistes ainetes õpitavat, sest õppimine seisneb eelkõige keeletoimingutes. Pole aga teada, kuivõrd teadlikult kirjaoskust koolis arendatakse ja milline on ópetajate enda seisukoht ses küsimuses. Sellest tõukuvalt on siinse uurimuse probleem selgitada, kuidas eesti keele ja kirjanduse õpetaja teksti vastuvõttu õpetab ja tekste süsteemse keeleõpetusega seob, et seeläbi leida võimalusi kirjaoskuse koostöiseks õpetamiseks aine ja keeleõppe lõimingus. Uuringu fookustamiseks vaadeldakse teksti vastuvõtuga seotud kirjaoskust. Juhindutakse põhistatud uurimuse põhimõtetest: esmalt luuakse teoreetiline raamistik ja seejärel analüüsitakse uurimisküsimuste kaupa õpetajate intervjuusid ning tehakse järeldusi kirjaoskusõppe arendamise võimaluste kohta ${ }^{2}$.

\section{Teoreetiline raamistik}

\section{Kirjaoskus koolis}

Traditsiooniliselt on kirjaoskust nähtud kui lugemist ja kirjutamist ning selleks vajalikku tehnikat (vt nt EKSS), mitmed autorid on aga mõistet laiendanud ja näidanud kirjaoskust kui sotsiaalset praktikat (Street \& Street, 1984). Samuti räägitakse kirjaoskusest kui olemisest (nt Burnett \& Merchant, 2015; Gee, 2003; Lankshear \& Knobel, 2018). Igal juhul on kirjaoskusel hariduse kontekstis eriti tähtis roll, sest inimesed omandavad õpitava keele kaudu ja nii on iga aineõpetaja ka kirjaoskuse õpetaja (Fisher \& Ivey, 2005). Kirjaoskus ei kujune aga iseenesest, vaid selle õpetamine vajab teadlikku suunamist ja teadvustamist. Seepärast püütaksegi seda kui üldpädevust tagada kõigi ainete vastutusel.

Ainealase lugemise ja tekstiga töötamise strateegiad võtab kokku termin ainekirjaoskus, mis seisab eraldi terminist ainepädevus (Shanahan \& Shanahan, 2008). Ainepädevus tähistab ainesisu omandamist, mõistetest arusaamist ja aine valdamiseks vajalikke õpioskusi. Ainekirjaoskus on aga ainetekstide eripära tundmine: erialase sõnavara ja väljenduslaadi kasutamine ning ainetekstide tarbeks sobilike lugemis- ja kirjutusstrateegiate rakendamine. Seega võiks kõigi ainete tunnitöö keskmes olla teadlik lugemine, kirjutamine, kuulamine ja autentse teksti vastuvõtt (Fisher \& Ivey, 2005; Soodla, Luptova, \& Puksand, 2013).

Artikkel on osa pikemast uuringust, mille järgmises etapis uuritakse teiste ainete tekstikasutust ning luuakse tervikülevaade. 
Samasuguseid eesmärke ja tegevusi hõlmab LAK-õpe (Mehisto et al., 2010). LAK-õppel on kaksikfookus: rõhuasetus on nii keeleoskusel kui ka aineteadmistel. Kuigi LAK-õppest räägitakse pigem võõrkeele õppimise kontekstis, on selge, et selle sisu on tugevalt põimunud kirjaoskusõppega ${ }^{3}$.

Kirjaoskuse kui suhtluspädevuse õpetamise viise ja ainetevahelist ühisosa aitab kirjeldada Ivaniči (2004) kirjutamisdiskursuste mudel ${ }^{4}$, mida toetavad ka Krogh' (2012) uuringud. Ivanič defineerib diskursust Gee (1996) järgi kui keele kaudu edasi antavaid väärtushinnanguid, uskumusi ja tähendusi. Kirjutamisdiskursuste mudel hõlmab kuut peamist tähenduslikku tervikut ehk kirjaoskuse õpetamise viisi: oskuste, sotsiaalse praktika, loovuse, protsessi, žanri ja sotsiopoliitilist diskursust. Oskuste diskursuse keskmes on korrektse kirjakeele omandamine, keeleteadmised. Sotsiaalse praktika diskursus tähendab funktsionaalset keelekasutust ehk kirjutamise ja lugemise õpetamist ühiskonnas toimimise, suhtlemise eesmärgil. Loovusediskursuse fookuses on õpilase isiksuse ja loominguline areng, tähtis on lugemisnauding ja huvi äratamine. Protsessidiskursus keskendub mõtlemise arengule ja teksti vastuvõtule kui protsessile: lugemist toetatakse ülesannete või sammsammuliste tegevustega. Žanridiskursus hõlmab teksti kui olukorrale sobivat suhtlusviisi: lugedes uuritakse teksti eesmärki, konteksti ja keelevahendeid. Sotsiopoliitiline diskursus avaldub kriitilise mõtlemise ja lugemise kujundamises, milles on tähtsal kohal kodanikukasvatus ja argumenteerimisoskuse arendamine. Diskursused ei ole rangepiirilised, samal tekstil ja toimingul võib korraga olla mitu eesmärki. (Ibid.)

\section{Uus kirjaoskus}

Ühiskonna ootused inimese kirjaoskusele muutuvad ajas ja tehniliste võimaluste arenedes, seetõttu rõhutatakse sotsiaalse praktikana toimiva kirjaoskuse deiktilist olemust (Leu, Kinzer, Coiro, \& Cammack, 2004), mis tähendab, et kirjaoskus on olukorrakeskselt muutuva sisuga. Tänapäeval ei saa me enam rääkida pelgalt ühest suhtlusmoodusest, kirjutamisest, sest sotsiaalne praktika on muutunud: sõnumeid edastatakse eri märgisüsteeme (pildiline, suuline, kirjalik, liikuv, žestiline jne) kombineerides, tähendus tekib nende koosmõjul (Kress, 2003). Paraku ei ole tänapäevasel kirjaoskuse mõistel ühist tähistajat: rägigitakse uutest kirjaoskustest, uuest kirjaoskusest, 21. sajandi kirjaoskusest ja mitmikkirjaoskusest (allpool kasutame terminit uus kirjaoskus). Peale mitme suhtlusmooduse kätkeb uus kirjaoskus kahte olulist mõõdet: tehnilisust ja

Võõrkeele kontekstis räägime keeleoskusest, emakeele kontekstis aga eeskätt kirjaoskusest, millel on võorkeelealases kirjanduses pigem kitsam tähendus (Kerge, 2011).

4 Kuigi mudeli keskmes on kirjutamine, sobib seda rakendada kirjaoskuse uurimisel laiemalt (Ivanič, 2004). 
laiahaardelisust. Tehniline mõõde märgib mitmesuguseid digiplatvorme, olgu selleks veebilehed, rakendused või programmid, kus ühel inimesel on ühe vahendiga võimalik rakendada mitut protsessi. Laiahaardelisuse all mõeldakse üleilmset võimalust ühte ja sama teksti koostöiselt luua, jagada ning toimetada (Lankshear \& Knobel, 2018). See tähendab, et tänapäeva keelekasutajal on võimalik suhelda mitmesuguste rakenduste ja programmide vahendusel ning vahetada mõtteid üle kogu maailma. Nii saab tekstide loomise ja suhtlemise kaudu kaasata palju laiemat inimeste ringi, kahandamata suhtluskiirust. Selline argi- ja töösuhtlus on tänapäeva inimese uus reaalsus, milleks ettevalmistamine peaks olema koolihariduse osa.

Sedasorti haridus pole siiski veel laialt levinud, palju räägitakse lõhest tänapäeva tekstide ja koolikirjaoskuse vahel (Burnett \& Merchant, 2015; Leu et al., 2004; Luukka et al., 2008; Puksand, 2014). Kumab isegi oht uut kirjaoskust ähvardavana kujutada (Burnett \& Merchant, 2015), kuid traditsioonilisele lugemisele-kirjutamisele vastandamise asemel tuleks näidata, kuidas uus kirjaoskus pigem rikastab tekstimaailma, pakkudes sõnumiloomeks uusi võimalusi, mille variatsioonirikkus tuleks tänapäeva maailmas hakkamasaamiseks omandada.

\section{Tekstikeskne emakeeleõpetus}

Tekstikesksus toob emakeeletundi ühest küljest uut laadi tekste, sest uus kirjaoskus kätkeb keeletahku (Lankshear \& Knobel, 2018), teisalt ka muude ainevaldkondade tekste, mis omakorda kasvatab aineülese koostöö vajadust. Nii puudutab kirjaoskuse õpetamine kõige enam eesti keele ja kirjanduse ainevaldkonda. Keeleõpetuse uuemaid suundi ongi tekstikeskne metoodika, mis taotleb oskust tekstis keelenähtusi märgata ja analüüsida ning teksti nende abil iseloomustada (Aruvee, 2017; Carter, 2003; Rättyä, 2013). Eelkõige tähendab see, et grammatikateadmisi ei õpetata eraldi, vaid autentsete tekstide kaudu. Kuna sellise käsitlusviisi korral on tekst kõige väiksem suhtlusüksus (Kerge, 2010), võimaldab see vältida olukorda, kus üksnes eraldatud sõnadele või vormidele keskendumisel jäävad keeleteadmised praktilisse suhtlusolukorda üle toomata. Samuti on tähtis vaadelda keelekasutusviise just tänapäevastes, mitut suhtlusmoodust kombineerivates sõnumites.

Tekstikeskse keeleõpetuse metoodika teoreetiline taust ulatub Halliday süsteemifunktsionaalsesse teooriasse, mis näitab, et tekstiloomes rakenduvad ühtaegu žanrile iseloomulik ülesehitus ja keelesüsteem (Halliday, 1985, 2005). Keelesüsteemi märkamist ja oskust seda funktsionaalselt kasutada nimetatakse ka metalingvistiliseks teadlikkuseks (Myhill, 2018; Rättyä, 2013). Selline teadlikkus saab aga areneda vaid siis, kui vallatakse lingvistilist metakeelt ehk teatakse nimetada keelemõisteid ning osatakse neid kirjeldada ja kasutada. 
Keelesüsteemi tundmata ei saa aga keelevahendeid tekstist üles leida, ära tunda ega analüüsida, seega ei tähenda tekstikesksus grammatika hülgamist.

Metalingvistilist teadlikkust toetab tugevalt Võgotskist lähtuv mõistestruktuuri areng: tuttavaid tavamõisteid tuleb eakohaselt laiendada ja viia nad teadusmõiste tasandile (Arro, 2014; Toomela, 2004). Tekstide kaudu keelesüsteemi avastamine just seda tähendabki: esmalt hoomab õpilane tekstis näiteks tegevusi, seejärel mõistab ta, mida tähistatakse terminiga verb. Sobivateks meetoditeks peetakse grammatika üle arutlemist (Dean, 2008) koos autentse teksti näidete kasutamise ja visualiseerimisega (Myhill, 2018; Rättyä, 2013).

Seega on eesti keele aine kirjaoskuse arendamise nurgakivi: kui teistes ainetes kasutatakse tekste ainepädevuse ja ainekirjaoskuse saavutamise eesmärgil, siis eesti keele tunnis juhitakse õpilane tekstis peituva süsteemi sügavama tasandini. Nii võibki eesti keelt pidada metaaineks, mis toetab teiste ainete eesmärkide saavutamist.

\section{Uuringu korraldus ja metoodika}

Teoreetilisest raamist lähtuvalt on siinse uurimuse eesmärk osutada emakeeleõpetajate kogemuse alusel eesti keele ja kirjanduse didaktika arenguvõimalustele ning kirjeldada eesti keele rolli suhtluspädevuse õpetamisel. Selle saavutamiseks otsitakse vastuseid kolmele uurimisküsimusele.

1. Kuidas avaldub eesti keele ja kirjanduse õpetajate kogemuses kirjaoskusega seotud koostöö?

2. Kuidas avaldub eesti keele ja kirjanduse õpetajate metoodilistes valikutes uus kirjaoskus?

3. Kuidas avaldub eesti keele ja kirjanduse õpetajate töös tekstikeskse keeleõpetuse metoodika?

Uuringu fookustamiseks vaadeldakse üksnes teksti vastuvõtuga seotud kirjaoskust, mida nähakse kui fenomeni, kogemusega seotud mitmekülgset nähtust. Kuna kirjaoskuse uurimisel on kaldutud üha enam just kvalitatiivse fenomenoloogia poole, et sügavamalt ja põhjalikumalt näha kirjaoskuse õpetamise nüansirohkust (Toomey \& Kitson, 2017), on ka praegusel juhul valitud etnometodoloogilist laadi uurimisviis (vt Garfinkel, 1984): õpetajaid vaadeldakse kui professionaale, kelle tööalased valikud, väärtushinnangud ja kogemus fookustatakse. Uurimuse metoodikas on rakendatud triangulatsioonipõhimõtet (vt Flick, 2017), mille kohaselt põhineb nii teooria, informantide ja andmekogumisviiside kui ka analüüsimeetodite valik kolmel tahul. Teisisõnu, peale selle, et eespool esitatud teoorial on kolm lähtekohta (kirjaoskus üldpädevusena, uue kirjaoskuse liigid ja tekstikesksus), on ka andmed kogutud kolmel viisil: uuringupäevikute ning individuaal- ja rühmaintervjuude teel. Samuti 
kasutatakse andmeanalüüsis kolme meetodit: esmalt rakendatakse suunatud sisuanalüüsi ja sisuanalüüsi (vt Krippendorff, 2004), mille tulemustel põhineb omakorda diskursuseanalüüs (vt Fairclough, 2003; Gee, 1996).

Uuring kestis septembrist 2017 juunini 2018 ja jagunes kolmeks etapiks. Esimeses etapis paluti ühel eesti keele ja kirjanduse õpetajal (allpool Teele, nimi muudetud, staaž 3 a) pidada uuringupäevikut kuue eesti keele ja kuue kirjanduse tunni kohta. Päeviku küsimused keskendusid kolmele didaktika peaküsimusele: mis tekstiga on tegu, kuidas tekstiga tunnis töötatakse ning miks seda tööd tehakse ehk mis on eesmärk? Päevikusse korjati andmeid viie kuu jooksul: oktoobrist 2017 veebruarini 2018. Teises etapis tehti õpetaja Teelega aprillis 2018 individuaalne intervjuu, kus paluti päevikule kommentaare ja esitati üldisemaid küsimusi kirjaoskuse õppe-eesmärkide kohta. Kolmandas uuringuetapis tehti kaks rühmaintervjuud. Üks rühm moodustati pikaaegse kogemusega pedagoogidest (eksperdirühm), teine alla 15aastase töökogemusega õpetajatest. Mõlema intervjuu alusena kasutati Teele päevikut ja intervjuud, mis saadeti osalejatele tutvumiseks kolm päeva enne rühmaintervjuud. Intervjuu ajaks olid kõik end teksti ja kõneainega kurssi viinud ning saanud mõtiskleda teksti pikitud intervjuuküsimuste üle. Mõlemad rühmaintervjuud tehti juunis 2018.

Eksperdirühma kutsuti isikliku meili ja Eesti Emakeeleõpetajate Seltsi meililisti kaudu õpetajaid, kes on juhtinud erialakoolitusi, osalenud riikliku õppekava eesti keele ja kirjanduse ainekava loomisel või koostanud õppematerjale. Uuringus osales neli õpetajat (allpool E4-E7) tööstaažiga 20-35 aastat. Seevastu fookusrühma õpetajad (N1-N3) leiti Eesti Emakeeleõpetajate Seltsi meililisti kaudu ning Tartu Ülikooli ja Tallinna Ülikooli viimase viie aasta vilistlaste seast. Üks kutsutu ei saanud intervjuul osaleda, nii vestles selles intervjuus kolm õpetajat, neist üks Skype’i teel. Nende tööstaaž oli 2-11 aastat.

Tabel. Uurimuse alusandmed ja analüüsimetoodika

\begin{tabular}{|l|ll|}
\hline Andmekogumisviis & Andmete maht & Analüüsimeetod \\
\hline Õpetaja uuringupäevik & $\begin{array}{l}\text { 12 tunni sissekanded, } \\
\text { 3066 sõna }\end{array}$ & $\begin{array}{l}\text { Suunatud sisuanalüüs, } \\
\text { sisuanalüüs }\end{array}$ \\
\hline $\begin{array}{l}\text { Intervjuu päevikut } \\
\text { pidanud õpetajaga }\end{array}$ & 1 tund $7 \mathrm{~min}, 6409$ sõna & $\begin{array}{l}\text { Suunatud sisuanalüüs, } \\
\text { sisuanalüüs, diskursuseanalüüs }\end{array}$ \\
\hline Eksperdirühma intervjuu & 1 tund 23 min, 19090 sõna & $\begin{array}{l}\text { Suunatud sisuanalüüs, } \\
\text { sisuanalüüs, diskursuseanalüüs }\end{array}$ \\
\hline Fookusrühma intervjuu & 1 tund 13 min, 12985 sõna & $\begin{array}{l}\text { Suunatud sisuanalüüs, } \\
\text { sisuanalüüs, diskursuseanalüüs }\end{array}$ \\
\hline
\end{tabular}


Eksperdirühma intervjuu oli fookusrühma omast pikem, sest kogenud õpetajatel olid pikemad vastused, mida soodustas väiksem distants vestlejate vahel, sest oldi juba varem tuttavad.

Intervjuud transkribeeriti TTÜ keeletehnoloogia labori automaatse transkriptsiooni rakenduse abil (vt Alumäe, Tilk, \& Asadullah, 2019) ja korrigeeriti käsitsi. Andmeid analüüsiti programmiga QDA Miner Lite (vt Lewis \& Maas, 2007), luues kolmele uurimisküsimusele vastavad koodid. Suunatud sisuanalüüsi tegemisel lähtuti Ivaniči kuuest diskursusest, võttes arvesse tema seisukohta, et diskursused ei eristu rangelt. Teisele ja kolmandale uurimisküsimusele vastamiseks loodi ise koodid (vt lisa).

Kumbki uurija kodeeris materjali iseseisvalt, seejärel koode võrreldi. Kui uurijad ei saavutanud üksmeelt, jäeti alles kõik võimalikud koodid. Pärast kodeerimist analüüsis esimene uurija kodeeritud andmeid diskursuseanalüüsi raamistikus, tuues esile sõnakasutuse, väljendid, laused ja grammatilised konstruktsioonid, mis moodustasid omavahel seotud tähendusliku terviku. Tulemusi kontrollis teine uurija.

\section{Tulemused}

Leitud diskursusi kirjeldatakse uurimisküsimuste kaupa. Esmalt analüüsitakse kirjaoskuse ühise vastutuse küsimust ning kirjeldatakse kirjaoskusealast koostööd ainete vahel. Teiseks antakse ülevaade, kuidas avaldus uue kirjaoskuse õpetamine, ja kolmandaks kirjeldatakse intervjuudes ja uuringupäevikus leidunud tekstikeskse keeleõpetuse viise.

Sillad on diskursus, mida iseloomustavad rohkete seoste esiletoomine ja võimaluste nägemine. Kuristikudiskursusele on iseloomulikud eitus, vastandus, seoste ja võimaluste puudumine ning takistavate tegurite nimetamine.

\section{Sillad ja kuristikud kirjaoskuse ning ainete vahel}

Ainetevahelisi sildu iseloomustas uuritavate õpetajate valmidus ja oskus lõimida eesti keele ainepädevusi ning teiste ainete tekste, kuristikele oli omane aga koostöö puudumine või eraldatuse ja distantsi väljendamine.

\section{Sillad kirjaoskuse ja ainete vahel}

Ainelõiming oli eelkõige sisuline või kirjutamiskeskne. Sisulise lõimingu algataja oli eesti keele ja kirjanduse õpetaja, kui ta vajas tuge mõne loetud teose teema käsitlemisel. Teiste ainete õpetajad vajasid emakeeleõpetajate sõnutsi abi tekstianalüüsis, et avada põhjalikult enda aine mingit alateemat või probleemi, mille kohta käivaid tekste loetakse ja seejärel arutatakse emakeeletunnis. Seega 
esildus sotsiopoliitiline diskursus: aine või ühiskonna aktuaalne probleem, käsitlusvõimalused eri ainevaldkondades (vt Ivanič, 2004).

Koostöö keskmes võisid olla ka oskused ja protsess, harva žanr, nt kui emakeeleõpetaja aitas teatris- või kinoskäigu järel vaadatut analüüsida või arvustust

kirjutada. Žanri- ja protsessidiskursus palju ei erinenud: neid sidus kirjutamine ja kirjatöö hindamine, mitte niivõrd žanri eripära ja eesmärgi esiletoomine. Emakeeleõpetajad tundsid vastutust eeskätt kirjutamise eest ja koostööga haakus siin tugevasti oskuste diskursus, mida kandsid väljendid õigekirja hindamine; keelevigade parandamine; sisu ühest, keel teisest ainest. Emakeeleõpetajate sõnul vajasid aineõpetajad nende tuge ka teksti liigenduse ja ülesehituse õpetamisel. E7 nägi kirjutamise lõimimisel õpilase vaatenurka: tema teeb ära suure töö, kuid erinevaid kihte on sellel tööl sees ja peal mitu. Mitmeid tekstitööga seotud kihte saavadki õpetajad eraldi avada ja hinnata. Selline koostöö võib samas tekitada õpilasele mulje, et keel eksisteerib ainult eesti keele tunnis ja on sealse õpetaja asi, mitte ei ole see üldine autentne suhtlusvahend nii elulistes kui ka õpiolukordades.

\section{Kuristikud kirjaoskuse ja ainete vahel}

Kuristikuks ainete vahel sai keele ja sisu eraldamine. Kuigi kõik uuringus osalenud õpetajad tegid mingil määral tekstipõhist koostööd, ei tunnetanud eriti eksperdirühma õpetajad otseselt vajadust jagada vastutust, vaid nägid seda ennekõike kirjakeele, mitte laiemalt kirjaoskuse õpetamise kontekstis. Nende sõnutsi pole teistel õpetajatel vastutuse jagamiseks piisavalt keelepädevust. Kuigi nooremad õpetajad mainisid, et tekstitööd tehakse mujalgi, arvasid nad, et tekstide analüüs ja keelekasutuse eripära on siiski nende pädevusvaldkonnas.

Keelele tähelepanu pööramist eeldab ka suhtluspädevus, kuid küsitletud ei tajunud, et seda tööd teistes ainetes tehakse. Eksperdirühma õpetajad leidsid, et ajaga on järjest vähenenud eesti keele kui eristuva distsipliini roll: keele instrumentaliseerimine jätab eesti keele süsteemi eripära varju. Eksperdirühma õpetajate põhimure oli tekstiliigipaljusus, mis on eesti keelde toonud eri teemad ja valdkonnad ning justkui suurendanud nende vastutust ka ainekeele eest, laiendades kuristikku eesti keele ainespetsifiliste nähtustega veelgi. Keelekasutusest kumas omavahelist konkurentsi.

E6: Teised ained on nii tähtsad kõik, teiste ainete õpetajad on tähtsad kõik.

Eksamitest kõneldes väljendasid eksperdirühma õpetajad kahjutunnet, mis tulenes sellest, et kirjanduse või eesti keele aine mõisteid enam eesti keele lõpueksamil ei küsita. Tähtis on tekstitöö, mis aga nende hinnangul kipub jääma ainuüksi nende vastutada. 
E4: No eesti keele eksamil ma ikkagi tunnetasin, et kogu vastutus lasub minul, mina pean Rooma numbrid ja sajandid selgeks tegema, mina pean taandamise lastele selgeks tegema.

E6: See ajalooga seotud teema näiteks riigieksamil on jah, no andke andeks, mina ei õpeta ajalugu.

See intervjueeritud emakeeleõpetajate põhimure päädis vajadusega panna kolleegid mõistma, et suhtluspädevus, sh lugemine ja kirjutamine, on aineteülene, kusjuures küsitletud tundsid, et just nemad peavad oma aine ise nähtavaks tegema. Kuristikku konstrueeriti nähtamatuse kujundi kaudu: kui E7 arvas, et keel on nähtamatu, laiendas E4 selle ka eesti keele õpetajatele.

E7: Eesti keele õpetajad näevad seda, kuidas keel avaldub ja mismoodi toimib ja mismoodi vorm on, eks, teised ei näe seda. Nii et selles mõttes selle pealekäimise peab tegema ikkagi eesti keele õpetaja, kuna teiste jaoks nähtamatu koht, nende jaoks ei ole seda olemas.

E4: Ometi kõik peame eksamile viima, meie, nähtamatud.

E6 pakkus, et võiks olla võimalus jälgida e-koolis, mis teistel õpetajatel parasjagu käsil - ilmselt on eesti keele õpetajalegi nähtamatu see tekstitöö, mida teised teevad. Samas kinnitati, et koostöömeelsus siiski aina kasvab, ehkki kokkulepped sõltuvad õpetajate isiklikest suhetest, koostöö sobitamise võimalustest ja läbirääkimiste õnnestumisest.

\section{Sillad ja kuristikud uue kirjaoskuse ning eesti keele vahel}

Uue kirjaoskuse silladiskursust iseloomustas õpetaja oskus näha seoseid uute tekstide ja suhtluskeskkondade ning eesti keele ja kirjanduse valdkonnapädevuse vahel. Siin jaotusid sillad kolmeks aladiskursuseks: sillaks audiovisuaalsete tekstide, veebi ja inglise keelega. Oli tugevamaid, aga ka nõrgemaid sildu, kus loodud seos paistis ajutine või juhuslikku laadi. Kuristikku iseloomustas uue võõrastamine.

\section{Tugev sild audiovisuaalsete tekstidega}

Intervjuude analüüs näitas, et multimodaalne tekst seostus uuritud õpetajatel nii sotsiaalse praktika, oskuste, protsessi- kui ka loovusediskursusega (vt Ivanič, 2004). Video ja filmi kasutus olenes mitmest tegurist: õpilaste valmisolekust, õppeprotsessist ja õpetaja eesmärgist. 
Teele: See oleneb sellest, mis eesmärgiga see tekst kasutusel on mingil määral, ja siis oleneb näiteks sellest, et kas ma tean, et mul on 7. tund või mul on 3. tund, et millises meeleolus nad suure tõenäosusega on ja millise vastuvõtlikkusastmega.

Videoklippe kasutati tasakaalustaja, huviärataja, elavdaja ja häälestajana, mis ehitab silla tunniteemani.

Lühemate videote kohta kasutati sageli sõnu jupp, katkend, lõik ja klipp, toodi esile eelnevad või järgnevad ópitegevused ning mainiti siis saame edasi liikuda, alguses tutvustav video. Videoklippe nähti lihtsa ja kiire viisina anda kõigile korraga ette materjal, mis juhatab õpilaste tähelepanu sisuni, pakkudes ühist kogemust.

Teisiti kasutati audiovisuaalset materjali, kas tervikteost või terviklikku katkendit (lühi- ja mängufilmid, saatekatkendid) tunni põhiosas. Kirjandustunnis esindasid audiovisuaalseid žanreid pigem filmikunsti näited, eesti keele tundides aga telesaated, nt nimetati ERRi veebilehte kui materjaliallikat. Mõlemas aines domineerisid eelkõige sotsiaalse praktika diskursus, multimodaalse teksti funktsionaalne vastuvõtt ja tekstiloome: suuline arutlus või kirjalik töö. Mängufilmi vaatamisel ilmnesid loovuse- ja žanridiskursus, sest olulised olid ka kunstižanrist tingitud väljendusvahendid või elamus.

E4: See on nii võimas - millised kujundid /.../ otsime kujundlikkust /.../ ja pärast seda ... vaikus on klassis.

Eesti keele tundi põimiti uut kirjaoskust ka videole subtiitrite lisamisel. Õpetajad nägid videos võimalust demonstreerida seda, mis kirjalikus vormis võib jääda esialgu kättesaamatuks - ehitati sild audiovisuaalse juurest kirjaliku juurde.

\section{Sild veebiga}

Tugevamaid sildu ehitati praktilise keelekasutuse ja e-ressursside vahel, nagu e-ajalehed, fotod, otsimootorid ja keeleallikad. Diskursustest olid siin olulised oskused, protsess, sotsiaalne praktika (vt Ivanič, 2004). E-keeleallikate kasutamist õpiti tundides eraldi ülesannete kaudu, e-keeleallikaid kasutati pidevalt, seejuures lubasid õpetajad N1, E6 ja E7 kasutada ka nutitelefone, et kujundada harjumus keelt kontrollida.

E7: See telefon on tal läbi elu kaasas, ja kui tekib harjumus, et sealt saab vaadata, võib-olla äkki vaatab siis ise ka, kui ta juba enam koolis ei käi. 
E-keeleallikatest nimetati õigekeelsussõnaraamatut, e-keelenõu, eesti keele käsiraamatut, võõrsõnade leksikoni, sünonüümisõnastikku ja seletavat sõnaraamatut. Kaks eksperdirühma õpetajat mainisid ka aimeajakirja Oma Keel kodulehte. Keelekorpusi ja -tööriistu ei nimetanud keegi.

Erinevalt õigekeelsussõnaraamatust kasutati muid keeleallikaid ja kodulehti pigem ülesandekeskselt ja ainesisule keskendudes.

E4: Ühes klassis ma käin Eesti Keele Instituudi leheküljel, lähme arvutiklassi ja ... nad peavad seal noh, liiklema ja natukene konspekteerima, mis nad teada saavad, palju üldse töötajaid, mis osakonnad on üldse, teadma ... mis asutus see normeerib meil siin seda keelt üldse, teeb murretega tööd. See on suur üllatus neile.

Kodulehti kasutati ka näiteks kodukandiga tutvumise ja silmaringi avardamise eesmärgil, põimides multimodaalse teksti lugemise ja koostamise oskust.

N3: Kodukoha asja annab uurida isegi siis, kui on pärit mujalt lapsed. Geoportaalis on kohapärimust sisestatud, maa-ameti rakenduse tutvustamist olen ka teinud, et mulle endale on ka see lemmiktund alati, kuhu ma tahan minna.

Nii ehitati sildu omakultuuri tundmise, veebis navigeerimise, üldiste ja veebispetsiifiliste tekstitööoskuste vahele, mis seostuvad peamiselt sotsiaalse praktika diskursusega. Näiteks kasutati JustFilmi ja Apollo raamatupoe veebilehte, kust leiti huvipärast lugemist-vaatamist, mis on üks uue kirjaoskuse tunnuseid ja haakub loovusega.

Teele ja E6 väitsid, et õpilased viibivad üha enam sotsiaalmeediakeskkondades, nii et isegi päevakajalised arvamuslood ja uudised võivad neist täielikult mööda minna, mistõttu on oluline suunata õpilasi tunnis meediaväljaannete veebilehtedele (sotsiopoliitiline ja sotsiaalse praktika diskursus). Suhtluskeskkonnad ei jäänud õpetajatele üldiselt võõraks, nad leidsid võimaluse sealse keelekasutusega (nt iseenda ja sõprade postitustega) töötada, milles avaldus otseselt sotsiaalse praktika diskursus.

E6: Me oleme teinud ka sõnastikke, näiteks, et võta nüüd oma need postitused, mis lühendid on /.../ Selliseid asju nagu oleme teinud küll, et analüüsi oma neid postitusi ... kuidas ja kellega suhtled, ja näed, mida nad kasutavad, nii et tee mingi väike sõnastik.

Uute veebitekstide käsitlemisel oli üsna iseloomulik see, et õpilane tõi näiteid ja tegi üldistusi õpetajale võõra kohta, kuid samas oli õpetaja see, kes ülesande andis. 


\section{Sild eesti ja võõrkeele vahel}

Inglise keelega ilmnes huvitav sild just uue kirjaoskuse kontekstis. Neli õpetajat (N2, N1, E6, E7) mainisid veebikeskkonna kasutamise näitena Google Translate'i, mille pakutud toortõlget pidi õpilane toimetama.

N1: Olen andnud reklaamtekste /.../ nad on proovinud sellised võib-olla paremasse eesti keelde panna, kui Google Translate annaks. Mulle meeldib see, et nad näevad sealt seda vahet, et sõnad on ju kõik olemas, aga et on oluline, mis vormis või mis järjestuses või kuidas neid sõnu kasutada.

Õpetaja N1 ülesanne demonstreeris ilmekalt eesti keele vormistikku ja keelelist eripära. Inglise keel oli siin sild, mis juhtis õpilased õpitavani. N2 väitis samuti, et tunnis tekitab huvi just inglise keele kasutamine.

Kõik õpetajad aga ei lubanud inglise keelt oma tundi. Kogenud ja noored õpetajad tõid paar näidet ingliskeelse video kasutamise kohta, samas kui E6 on keeranud ingliskeelse video näitamisel hääle maha. Seega ei saanud seda silda pidada kuigi tugevaks, kuid see oli samas võrdlemisi uus ning toetub eeskätt inglise keele populaarsusele ja kättesaadavusele. Silla kasutamine sõltus eesti keele õpetaja valmidusest luua ühendus, mis olenes sellest, kas see aitas tema aines teemasid omandada ja pädevusliike arendada.

\section{Kuristikudiskursus: uued žanrid ja suhtlusmoodused}

Vähe kasutati tekste, mis on seotud õpilaste enda tekstimaailmaga, nt meelelahutuslike videote, piltide või videoblogidega. N2 arvas koguni, et õpilastel ei olegi eriti tekstimaailma, millega teised nõustusid: Seal ei olegi nagu mingit tekstimaailma nii väga. Kuristik väljendus siin eelkõige eitusena: suurem osa küsitletutest möönis, et nad ei kaasa õpilaste igapäevatekste oma tundi.

Eksperdirühma õpetajad tõdesid, et õpilaste loetavad tekstid on muutunud lühikeseks ning pikkade tekstide lugemine vaevaliseks.

E6: Ja siis orienteeritus muidugi nendele lühematele tekstidele. Tagasisides ütles [õpilane] ka, et sel aastal lugesime liiga paljusid tekste, et pidi süvenema, et nagu selliseid tekste võiks vähem olla.

E6 väljend nendele lühematele tekstidele peegeldas distantsi õpilaste tekstimaailmaga, mida viimaste ootused omakorda pikendasid. Ent oli olnud ka juhtumeid, kus õpilased olid toonud uued tekstiliigid ise tundi ja tutvustanud neid õpetajatele. 
N3: Et kui ma palun koostada sellist „Piiririigi“ käsitluses, et kui tuli fotolavastusi teha, aga tulid hoopis giphy'd. Et see on nagu teistpidi, õpilastelt tulnud.

Paraku selgus, et üha lisanduvad veebispetsiifilised žanrid - nagu meemid ja giphy'd digitaalsete remiksidena ${ }^{5}$, millel on samuti oma sõnum ja eesmärk olid õpetajatele võõrad ega seostunud neil eesti keele ainepädevusega. Ent tekstide paljusus seab oma piiranguid ning vajadus kasutada keelt asjalikus suhtluses ei kao. Nii tegid õpetajad valiku, mida suunas eelkõige eesti keele õpetuse ja põhikooli peaeesmärk - kirjakeele valdamine.

E7: Mina olen mõnikord võtnud õpilase rolli selle koha pealt, et mina ei saa aru, mis teil siin kirjas on praegu, tõlkige palun. Need tekstid tulevad nende valikul ja siis saab arutada ..., kuidas lühendatakse ja mis see sümboli märk on. Ma ei pea ju ópetaja alati olema.

Õpetaja E7 jaoks oli võõrast liiki tekstidel siiski tähendus, ning kui ta on palunud tekstid ümber jutustada ja nende keelt uurida, on ta seeläbi arendanud funktsionaalset keeleoskust (sotsiaalse praktika diskursus) - sild aineni ei ole siiski kaugel.

Üks kuristiku väljendusi oli õpetuse metatasandi puudumine. Õpetajad ei seletanud, kuidas mingit uut kirjaoskustoimingut tehakse, ja nii jääb õpilase vastutusele see välja uurida. Filmiomane pildikeel pälvis tähelepanu ainult kogenud õpetajate ütlustes (E7, E5, E4) ja tõusis nooremate seas esile vähesel määral. Näiteks jäi õpetaja Teelel pildikeel kõrvale, kui ta palus õpilastel video teha. Seevastu N3 leidis, et video loomine ei kuulugi eesti keele ja kirjanduse õpetaja valdkonda, sest mõte ei ole ju režissööri algõpet anda. Samuti ei kirjeldanud N2 ja N3, mis programmiga või kuidas subtiitreid loodi või kodulehte täiendati.

\section{Sillad ja kuristikud tekstikeskses keeleõpetuses}

Keeleõpetuse ja tekstitöö ühendamist iseloomustas peamiselt veendumus, et autentsed tekstid on olulised, kuid tekstikeskse keeleõppe metoodika rakendamisest kõneldes leiti mitmeid takistusi. Siin oli raske näha tugevaid sildu, pigem tulid esile nõrgad ühendused.

Knobel (2017) tähistab terminiga remiksimine „olemasolevate teoste kombineerimist viisil, mille tulemusena tekib uus teos või toode“ (lk 9). Digitaalne remiks on multimodaalseid tekste kokku segav uus tekst, mille loomisel on kasutatud digivahendeid ja -rakendusi. 


\section{Kitsas purre: sõnavara ja tekstid}

Sõnavara- ja tekstitöö sai tähelepanu sotsiaalse praktika, oskuste ja protsessidiskursuses, kokkupuutepunkte oli ka sotsiopoliitilise, loovuse- ja žanridiskursusega (vt Ivanič, 2004). Sõnavaraõpetuse ja tekstide vahelist ühendust iseloomustas kõige paremini sõna purre. Ühest küljest kasutasid õpetajad tunnis sageli e-keeleallikaid, kuid samas jäi kõrvale palju muid keeletehnoloogilisi võimalusi. Siiski oli sõnavaratöö selgelt tekstiga seotud.

Õpetajate selgitustest koorus mure ahta sõnavara üle (oskuste diskursus), kuid muid näiteid toodi vähe. Leidus ka selliseid näiteid, kus otsiti lugemise või kirjutamise ajal sõnade tähendusi (protsessidiskursus).

N3: Millele ma olen pidanud tähelepanu eraldi suunama, on sünonüümisõnastiku olemasolu. Et kui sõnakordusi tekstides õpilasel palju on, siis tihti /.../ põhikoolist pole tulnud seda teadmist, et sünonüüme saab ka vaadata, et tegelikult neid saab isegi ÕSist noppida.

Internetis on aga rohkelt allikaid ja rakendusi, mille toel uurida sõnade päritolu, tundetooni, koosesinemust või sagedust ja selle muutusi ajas, kontrollida sõna liiki ja vorme jne. Need võimalused uurimismaterjalis esile ei tulnud, mis näitab, et uuem keeletehnoloogia oli intervjueeritavatele võõras.

\section{Kerge sild: lauseõpetus ja tekstid}

Rohkem tekstipõhist tööd tegid uuritavad õpetajad lauseõpetuses. Kõik õpetajad tõid näiteid, kuidas tunniteemaga haakuvast autentsest tekstist kustutatakse kirjavahemärgid ja palutakse õpilastel need siis lisada. N1 on lasknud ka õpilastel endil selleks tekste valida, hinnates autentse keelematerjali algupära. Tema sõnul võivad keelenähtuste õpikunäited vahel mõjuda koomiliselt ning jääda lihtsakoeliseks, seevastu autentsed tekstid on keerulisemad ja loomulikumad.

N1: Lauseõpetuse juures, et siis ma olen küll kasutanud, et siis on nagu kuidagi ... need laused on võib-olla natukene nendepärasemad kui need võib-olla vana aja õpikulaused või sellised ... mõnikord ... on kuidagi nagu välja imetud, et mõnikord nad ütlevad, et keegi ei räägi ju niimoodi ... Elulisemad tekstid on natukene võib-olla paremad kasutada.

Autentses tekstimaterjalis võis esineda vigu, mõnikord otsiti vigaseid tekste meelega.

Teele: Ma ei ole kirjavigu parandanud küll originaaltekstides. Pigem ... on need olukorrad, kus nad näitavad, näe, õpetaja, siin on viga. Et siin tegeli- 
kult peaks olema reeglite järgi. Siis me oleme sellest rääkinud, et inimesed on inimlikud ja eksimine on inimlik. Ja näiteks ka seda, et me näeme seda, et erinevatel tekstidel on ka erinevad õigekirjanõuded mingil määral.

E7 ja E4 kinnitasid autentse keelematerjali tähtsust ning mainisid samas, et õpilaste teadmiste ja oskuste vahel on tühimik: lünki osatakse harjutustes täita, kuid õpitud vorme ei suudeta enda teksti üle kanda.

Kui leidus metoodilisi juhendeid, eeskujusid, rakendasid õpetajad ka neid meetodeid, mille peale ise ei tuldud. E4 rääkis, et õppematerjali kaasautorina tuli tal kindla grammatikanähtuse tekstikeskseks õpetamiseks tekste otsida, seejuures kinnitas ta, et ilma selle töökogemuseta ta ilmselt näidetest reeglini jõudmist ei õpetaks. Seevastu E7 oli tekstikeskse metoodika täielikult omaks võtnud ja kasutas seda regulaarselt. Ta on rakendanud aktiivõppemeetodeid, suunates ópilasi autentsete tekstidega töötama, vigu analüüsima ja iseend hindama.

Žanri keelelist eripära uuriti tundides üldiselt vähe, kuid leidus näide, kus N1 ehitas silla teksti ja eriomase lauseehituse vahele. N2 keskendus žanri kompositsioonimustri funktsionaalsele lugemisele.

N1: Olen kasutanud just näiteks ajakirjandusteksti, et seda analüüsida või vaadata, et missugust lauseehitust siis näiteks kasutatakse kuskil mõnes ... näiteks on Postimehes hästi tihti kasutusel.

N2: Vahel kaotanud näiteks lõigud ära või lasen panna lõikudele alapealkirju, ... et sisust nagu aru saada, paremini. Noh, erinevaid asju annab tegelikult teha tekstiga.

Üsna harjumuspärane oli kujundite otsimine ilukirjandustekstidest (E4, E5, Teele) või õpitud mõistete ja keelenähtuste avastamine meediatekstidest (Teele, N1), kuid sügavamale keelevahendite analüüsis eriti ei mindud. Levinud oli arusaam, et keelt on parem õpetada autentsete tekstide abil, ja jõudumööda seda ka rakendati - sellele saab rajada induktiivse grammatikaõpetuse metoodika.

\section{Kaljulõhe: keelesïsteem ja tekstid}

Tekstikeskse keeleõpetuse metoodika ja selle rakendamise vahel oli kuristik ka siis, kui metoodika oli tuttav ja kasutustahe olemas. Tekstitöö haakus pea kõigi diskursustega, nõrgalt žanridiskursusega.

Mõni õpetaja ei rakendanud tekstikeskset keeleõpet üldse (E5), mõni kasutas seda ainult osa teemade juures või vanemate õpilastega (E6, N1, N2, N3). Seda kuristikku võib nimetada kaljulõheks: tekst on ainuke autentne grammatika- 
avaldus, kuid põhjus, miks neid omavahel ei lõimitud, on sügav. Enamik õpetajaid tundis induktiivse keeleõppe meetodit, kuid rakendas seda harva. Teksti varal keelesüsteemi õpetada takistavat ettevalmistuse ajamahukus, liigne individuaalsus, õpilaste erinev tase, ootus kognitiivselt võimekamate õpilaste järele.

N1: Ma olen seda meelt, et /.../ põhikoolis niimoodi teksti põhjal, siis peab olema väga tugev õpilane, väga tugev klass, et nad saaksid sellest nagu kohe aru või et neile nagu efekti annaks, aga see ajaline ressurss on niivõrd piiratud, et ei saa nagu ülemäära selle peale aega kulutada. Et siis pigem ikkagi traditsiooniline grammatika õpetamine.

Ühe väärarusaamana tuli esile, et pearaskuseks peetakse vajadust leida n-ö õiged tekstid, mis demonstreeriksid õpetatavat keelenähtust kõige paremini, nt sa pead ju andma sellise hea teksti, milles oleks ainult need... näiteks tegusõna olevikus (E4). E7 aga nägi, et kasutada võib mistahes teksti, sest oluline on tuua õpetatav aspekt esile - tuleb vaid harjuda esitama õigeid ja asjakohaseid küsimusi. Ka ei nähtud ühendusi keelesüsteemi ja tekstide vahel.

Selgelt ilmnes kuristik varasema õpi- või töökogemuse ja ülikoolis õpetatava vahel. N2 ja N3 on õpetajaameti omandanud pärast 2011. aasta õppekavade vastuvõtmist ning tundsid tekstikeskset metoodikat, kuid rõhutasid traditsioonilise metoodika eeskuju tugevat vastukaalu.

N3: Liigne austus on vanemate kolleegide vastu ja mulle tundub, et mis nad teevad, on õige.

Tegu oli sügava lõhega: autentseid tekste tähtsustati, metoodikat tunti, kuid rakendamine jäi mitme põhjuse taha, nagu metoodikakoolituste ja -materjalide nappus ning praktikute eeskuju puudumine.

\section{Arutelu ja järeldused}

Eesti keele ja kirjanduse õpetajate kogemusest paistis vajadus jagada vastutust kirjaoskuse õpetamise eest - seda tundsid nii intervjueeritavad kui ka ütluste järgi nende kolleegid. Kirjaoskuse ühise õpetamise viisina lõimiti peamiselt ainesisu, kuid tehti ka tekstitööd. Ivaniči kirjaoskusdiskursustest (2004) joonistusid ühisosana selgelt välja oskuste, sotsiaalse praktika, sotsiopoliitiline ja protsessidiskursus. Oskuste ja sotsiaalse praktika diskursuse korral vajati eesti keele õpetaja tuge teksti vormistamisel, eriti viitamisel ja teksti struktureerimisel, aga ka õigekirjaküsimustes. Sotsiopoliitilise ja protsessidiskursuse korral avati tähtis teema või probleem mitme aine vaatenurgast, seejuures eesti keele ja kirjanduse õpetaja toetas seda arutelu tekstianalüüsiga. Aineõpetajad aga 
pakkusid emakeeleõpetajale tuge kirjandusteose teema või ajastu tausta avamisel.

Näha oli ka, et uuritud eesti keele ja kirjanduse õpetajad toetasid teiste ainete ainekeele omandamist, kuid tajusid samas, et teevad seda kohati enda aine arvelt, mis väljendus konkureerivas kõnepruugis (vt Slabina \& Aava, 2019). Kirjaoskuse metoodikute sõnul aitab aga autentsete tekstidega töötamine ja lugemisoskuse õpetamine ainepädevust saavutada (McArthur, 2012; Shanahan \& Shanahan, 2008), samuti on ainemõistete ja tekstidega töötamine peamine LAK-õppe võte (Mehisto et al., 2010). LAK-õpet eesti kooliga siiski ei seostata, kuid leidude põhjal võis märgata valmisolekut selles suunas liikuda. Siin oleks abi asjakohasest õppekavakorraldusest, aga oma osa on täita ka koolil, kuna koostöö, mis kirjaoskuse ühisõpet toetaks, sõltub koolikultuurist (Slabina \& Aava, 2019).

Eesti keele ja kirjanduse õpetajate intervjuudest üksi ei selgu, kui aktuaalne on selline suund teiste ainete vaatevinklist ja millisena näevad aineõpetajad oma rolli suhtluspädevuse tagamisel (Soodla et al., 2013), mistõttu vajab see teema edasist uurimist. Uuringu jätkamine on vajalik seda enam, et otsene tegelemine ainetekstide ja neis kasutatavate keelevahenditega, millest teistes ainetes jääb vajaka, tähtsustub veelgi, kui eesti kooli lisandub teise emakeelega õpilasi, aktualiseerides LAK-õppe nn kaksikfookuse.

Arvestades kirjaoskusõppe jagatud vastutust, võiks koolihariduses rakendada aga pigem kolmikfookust. Tekstitöö võiks kätkeda kolme aspekti: ainepädevust, ainekirjaoskust ja metalingvistilist teadlikkust. Üksteisega otseselt mitte seotud ainepädevuse ja metalingvistilise teadlikkuse ühisosaks oleks sel juhul ainekirjaoskus ehk kõigi õpetajate jaoks oluline töö aines loetavate erialaste tekstidega, sest lugemisstrateegiad ja ainekeele eripära uurimine toetavad nii keeleõpet kui ka aine omandamist (McArthur, 2012; Shanahan \& Shanahan, 2008). Ühist tekstitööd võiks praktikas alustada ainesisust, mis avatakse lugemispalade või visuaalse materjali kaudu, ja seejärel jätkata ainekeele (eriti oskussõnavara) uurimisega. Viimase kihi laob eesti keele õpetaja, juhtides õpilaste tähelepanu metalingvistilisele plaanile, mis uuringu järgi on emakeeleõpetuse tugev külg, ehkki see ei ole tingimata tekstikeskne. Nii saavad tugevneda aineteadmised ja areneda lugemisoskus ning keel kui tähenduse kandja muutub nähtavaks.

Tekstitöösse põimituna tugevdab keelesüsteemi uurimine ehk metalingvistilise teadlikkuse loomine arusaama, et grammatika avaldub tekstides žanriomasel viisil ja on alati tähenduslik (Carter, 2013; Halliday, 2005; Rättyä, 2013). Emakeele ja miks mitte ka muu aine kirjaoskust aitaks grammatikaga siduda žanriõpetus (Dean, 2008; Knapp \& Watkins, 2010), mis seisneb tuttava tekstiliigi keelevahendite uurimises ja järelduste tegemises selle kohta, milline mõju on uuritavatel grammatilistel vormidel tähendusele ja toimingule. 
Uurimistulemustest ilmneb, et žanridiskursus on praegu nõrk: tekstide uurimisel jäi žanrile omane keelekasutus pigem kõrvale, sillana toimisid mõneti lauseõpetus (peamiselt küll kirjavahemärgistus) ning funktsionaalne lugemine ja kirjutamine. Suurem osa uuringus osalenud eesti keele õpetajaid ei rakendanud tundides täiel määral tekstikeskset keeleõpetust, mida peeti liialt õpilaskeskseks ja aeganõudvaks ning pigem kognitiivselt võimekatele õpilastele sobivaks. Kuristik tekstikeskse keeleõpetuse teoreetilise tausta ja koolipraktika vahel näitab, et emakeeleõpetus vajab metoodilisi materjale, koolitusi ning häid eeskujusid, mida edasistes uuringutes katsetada.

Arutlemis- ja lugemisstrateegiad, loovkirjutamine jm tekstitöö võiksid näidetena figureerida õpetajakoolituse ainetes (McArthur, 2012). Sedamööda kinnistuks ka napp arusaam, et kõik õpetajad on keeleõpetajad (Fisher \& Ivey, 2005) ja et legaalselt on vastutus kirjaoskuse õpetamise eest ühine (PRÕK, $2011, \S 4)$.

Uue kirjaoskuse temaatika uurimisel paistis silma, et uut kirjaoskust on asutud haakima oma ainega, kuid see tegevus vajab suunamist ja arendamist omal algatusel õpilaste igapäevatekste pigem ei kasutatud, sest seost ainepädevusega oli raske näha. Küll aga on eesti keele ja kirjanduse õpetajad teinud katsetusi oma oskuste ja võimaluste piires ning samas tasakaalustanud multimodaalseid tekste paberi ja pliiatsiga töötades. Selline tasakaal on loomulik (Burnett \& Merchant, 2015; Rowsell, 2014; Toomey \& Kitson, 2017) ja nii peab ka jääma, kuid teisalt vajab uue kirjaoskuse arendamine uut mõtteviisi ja laiemat teadvustamist (Lankshear \& Knobel, 2018; Leu et al., 2004) ning sellega tuleb igapäevases koolitöös arvestada. Näiteks toonitab Knobel (2017) digitaalsete remikside tugevat seost loovusega, sest kui õpilane on loonud kas või amatöörlikult ise uue tähenduse, on ta seda teinud mingil eesmärgil. Oluline pole siinkohal korrektsus või kasulikkus, pigem inimese loomingu väärtustamine (ibid.). Tähtis on jõuda kaugemale ekraanifunktsioonist ning õppida digivahendeid kui keskkondi kasutama (Lankshear \& Knobel, 2018) nutisuhtluse igas etapis: nii kriitiliselt infot vastu võttes, seda vahetades kui ka ise tekste luues (Burnett \& Merchant, 2015). Siingi võiks õpetajakoolituse ainetes arvesse võtta kirjaoskuse muutunud olemust ning demonstreerida viise, kuidas uut kirjaoskust arendada ühes ainepädevusega.

Uuritavad kasutasid tundides üsna palju visuaalset materjali, peamiselt õpilaste häälestamiseks ja tunni elavdamiseks, kuid ka pikemates ülesannetes, mil võrreldi ilukirjandusteost ekraniseeringuga või vaadati videoid kirjutamise või arutlemise eesmärgil. Visuaalne metakeel pälvis tundides küll mõningast tähelepanu, kuid visuaalsete sõnumite (kriitiline) lugemine ja koostamine on tänapäeval sedavõrd vajalik oskus, et selle arendamisel ei saa loota üksnes aineõpetajate oskusele neid enda ainega siduda. Tähtis on eelkõige uue kirjaoskuse 
rakendamine ja ülekandmine enda harjumustesse (Lankshear \& Knobel, 2018), mis tähendab veelgi sisukamat tööd uute väljendusvõimaluste õppimisel ja katsetamisel.

Praegune uuring ilmestas, kuidas intervjueeritud õpetajate kogemuses peegeldusid teoreetilised seisukohad kirjaoskuse vastutuse, uue kirjaoskuse ja tekstikeskse keeleõpetuse küsimuses. Uuring andis suundi ja mõtteid kirjaoskusõppe arendamiseks. Tulemustele toetudes saab esitada kuus praktilist soovitust.

1. Õpetajakoolituse didaktikaainetes tuleks rohkem arvesse võtta uut kirjaoskust ja õpilase tekstimaailma ning pidada silmas nende jätkuvat muutumist. Tuleb tagada, et uus kirjaoskus kui suhtluspädevuse osa oleks tugeva teadusliku taustaga.

2. Uue kirjaoskuse arendamine vajaks koolis selget ja süsteemset tööd. Ühe võimalusena võib põhikoolis välja töötada spetsiaalselt uuele kirjaoskusele keskenduva lõiminguaine. Ainekava võiks anda õpitulemused, kuid iga kool saaks sisu ja lõimitavad ained ise valida ning teha koostööd asjatundjatega väljaspool kooli.

3. Kirjaoskuse õpetamisel võiks silmas pidada kolmikfookust. Selle rakendamist, sh ainekirjaoskust saab suunata õpetajakoolituse ja täienduskoolitusprogrammide ning metoodiliste lisamaterjalidega. Ühe võimalusena võiks kasutusele võtta LAK-õppe põhimõtted.

4. Tekstitööd hõlbustaks tekstide jagamise (ja tekstitöönäidete) keskkond. Väärtuslik võib olla ka tekstiotsingu veebirakendus, mis toimiks avatud tekstikorpusena. Tekstikorpuseid ja teisi keeletehnoloogilisi rakendusi tuleks eesti keele ja kirjanduse õpetajatele veelgi tõhusamalt tutvustada.

5. Tekstitöö ja keelesüsteemi ühendamine emakeeleõpetuses vajaks rohkelt näiteid ja metoodilist tuge.

6. Inglise keele populaarsust silmas pidades võiks arendada tõlkimisele keskenduvat metoodikat, kuid kindlasti ei tohiks see käia eesti keele aine arvelt, vaid inglise keele õpetajaga koostöös.

Kuidas iganes kirjaoskuse õpetamist arendada, tuleks arvestada, et eesti keelt ei peaks õpilastele reklaamima teiste ainete kaudu, vaid vastupidi - eesti keel peaks olema näha ja tunda igas aines ja igal pool kui tähenduste kandja ning eesti kooli põhieesmärk.

\section{Tänusõnad}

Täname professor Krista Kerget heade nõuannete eest artikli kirjutamisel. Samuti täname kõiki uuringus osalenud õpetajaid. 
Uuringut on toetatud Tallinna Ülikooli uuringufondist, projekt TF/818 „Autentsete tekstide kasutamine põhikoolitundides“.

\section{Kasutatud kirjandus}

Alumäe, T., Tilk, O., \& Asadullah (2018). Advanced rich transcription system for Estonian speech. In K. Muischnek \& K. Müürisep (Eds.), Human language technologies - the Baltic perspective. Proceeding of the Eighth International Conference Baltic HTL 2018 (pp. 1-8). Amsterdam: IOS Press.

Arro, G. (2014). Children's self-reflection ability and its relations to the word meaning structure: Signs of life beyond the five-point scale format (Doctoral dissertation). Tallinn: Tallinna Ülikooli Kirjastus.

Aruvee, M. (2017). Tekstikeskne keeleõpetus põhikoolis: Teoreetiline taust, vastutuse jagamine ja metoodika. M. Erelt (toim.), Emakeele Seltsi aastaraamat, 62(2016) (lk 9-37). Tallinn: Emakeele Selts. https://doi.org/10.3176/esa62.01

Burnett, C., \& Merchant, G. (2015). The challenge of 21st-century literacies. Journal of Adolescent \& Adult Literacy, 59(3), 271-274. https://doi.org/10.1002/jaal.482

Carter, R. (2003). Language awareness. ELT Journal, 57(1), 64-65. https://doi.org/10.1093/elt/57.1.64

Dean, D. (2008). Genre theory: Teaching, writing, and being. Urbana: National Council of Teachers of English.

EKSS = Langemets, M. (toim.) (2009). Eesti keele seletav sõnaraamat. Tallinn: Eesti Keele Sihtasutus. Külastatud aadressil https://www.eki.ee/dict/ekss/index.cgi.

Fairclough, N. (2003). Analysing discourse: Textual analysis for social research. London, New York: Routledge.

Fisher, D., \& Ivey, G. (2005). Literacy and language as learning in content-area classes: A departure from "every teacher a teacher of reading". Action in Teacher Education, 27(2), 3-11. https://doi.org/10.1080/01626620.2005.10463378

Flick, U. (2017). Mantras and myths: The disenchantment of mixed-methods research and revisiting triangulation as a perspective. Qualitative Inquiry, 23(1), 46-57. https://doi.org/10.1177/1077800416655827

Garfinkel, H. (1984). Studies in ethnomethodology. Cambridge: Polity Press.

Gee, J. P. (1996). Social linguistics and literacies: Ideology in discourses (2nd ed.). London: Falmer.

Gee, J. P. (2003). What video games have to teach us about learning and literacy. New York: Palgrave Macmillan.

Halliday, M. A. K. (1985). An introduction to functional grammar. London, New York: Routledge.

Halliday, M. A. K. (2005). On matter and meaning: The two realms of human experience. Linguistics and the Human Sciences, 1(1), 59-82. https://doi.org/10.1558/lhs.2005.1.1.59

Ivanič, R. (2004). Discourses of writing and learning to write. Language and Education, 18(3), 220-245. https://doi.org/10.1080/09500780408666877 
Kerge, K. (2010). Tekstikeskne keeleõpetus põhikoolis. M. Kadakas (koost.), Põhikooli valdkonnaraamat „Eesti keel ja kirjandus“. Tallinn: Riiklik Eksami- ja Kvalifikatsioonikeskus.

Kerge, K. (2011). Tõlkevõhik keele- ja lugemisoskuse valdkonna terminivarast. Philologia Estonica Tallinnensis, 13(0), 91-114.

Knapp, P., \& Watkins, M. (2010). Genre, text, grammar: Technologies for teaching and assessing writing. New Delhi: Orient Blackswan.

Knobel, M. (2017). Remiksimist, kirjaoskust ja loovust käsitleva teaduskirjanduse analüütiline ülevaade. Eesti Haridusteaduste Ajakiri, 5(2), 8-30. https://doi.org/10.12697/eha.2017.5.2.02a

Kress, G. (2003). Literacy in the new media age. New York, London: Routledge.

Krippendorff, K. (2004). Content analysis: An introduction to its methodology (2nd ed.). Thousand Oaks: Sage.

Krogh, E. (2012). Writing in the literacy era: Scandinavian teachers' notions of writing in mother tongue education. In I. Pereira \& B. Doecke (Eds.), L1 - educational studies in language and literature, 12. A contribution to the inescapability of language (pp. 1-28). https://doi.org/10.17239/L1ESLL-2012.03.01

Lankshear, C., \& Knobel, M. (2018). Education and 'new literacies' in the middle years. Literacy Learning: The Middle Years, 26(2), 7-16.

Leu, D. J., Kinzer, C. K., Coiro, J. L., \& Cammack, D. W. (2004). Toward a theory of new literacies emerging from the Internet and other information and communication technologies. In R. B. Ruddell \& N. J. Unrau (Eds.), Theoretical models and processes of reading (5th ed., pp. 1570-1613). Newark: International Reading Association. https://doi.org/10.1598/0872075028.54

Lewis, R. B., \& Maas, S. M. (2007). QDA Miner 2.0: Mixed-model qualitative data analysis software. Field Methods, 19(1), 87-108. https://doi.org/10.1177/1525822X06296589

Luukka, M.-R., Pöyhönen, S., Huhta, A., Taalas, P., Tarnanen, M., \& Keränen, A. (2008). Maailma muuttuu - mitä tekee koulu? Äidinkielen ja vieraiden kielten tekstikäytänteet koulussa ja vapaa-ajalla. Jyväskylä: Jyväskylän yliopisto, Soveltavan kielentutkimuksen keskus.

McArthur, K. G. (2012). The metalinguistic protocol: Making disciplinary literacies visible in secondary teaching and learning. Reading Horizons, 52(1), 26-55.

Mehisto, P., Marsh, D., Frigols, M.-J., Võlli, K., Asser, H., \& Kärema, T. (2010). Lõimitud aine- ja keeleõpe. Tallinn: Integratsiooni ja Migratsiooni Sihtasutus Meie Inimesed.

Myhill, D. (2018). Grammar as a meaning making resource for improving writing. Working on grammar at school in L1-education: Empirical research across linguistic regions. L1-Educational Studies in Language and Literature, 18, 1-21. https://doi.org/10.17239/L1ESLL-2018.18.04.04

PRÕK, 2011 = Põhikooli riiklik õppekava (2011). Riigi Teataja, RT I 14.01.2011, 1. Külastatud aadressil https://www.riigiteataja.ee/akt/114022018008.

Puksand, H. (2014). Teismeliste lugemisoskuse mõjutegurid (doktoritöö). Tallinn: Tallinna Ülikooli Kirjastus.

Rowsell, J. (2014). Toward a phenomenology of contemporary reading. Australian Journal of Language and Literacy, 37(2), 117-127. 
Rättyä, K. (2013). Languaging and visualisation method for grammar teaching: A conceptual change theory perspective. English Teaching: Practice and Critique, 12(3), 87-101.

Shanahan, T., \& Shanahan, C. (2008). Teaching disciplinary literacy to adolescents: Rethinking content-area literacy. Harvard Educational Review, 78(1), 40-59. https://doi.org/10.17763/haer.78.1.v62444321p602101

Slabina, P., \& Aava, K. (2019). Õpetajate koostöise õpikultuuri kogemused Eesti üldhariduskoolide näitel. Eesti Haridusteaduste Ajakiri, 7(1), 76-100. https://doi.org/10.12697/eha.2019.7.1.04

Soodla, P., Luptova, O., \& Puksand, H. (2013). Suhtluspädevus. E. Kikas \& A. Toomela (toim.), Õppimine ja õpetamine kolmandas kooliastmes. Üldpädevused ja nende arendamine (lk 94-110). Tallinn: Eesti Ülikoolide Kirjastus.

Street, B. V., \& Street, B. B. (1984). Literacy in theory and practice (Vol. 9). Cambridge, New York: Cambridge University Press.

Toomela, A. (2004). Mõtlemise areng ja õppekava. Haridus, 1, 12-17.

Toomey, M., \& Kitson, L. (2017). Engaging the enemy: Computer games in the English classroom. Literacy Learning: The Middle Years, 25(3), 38-49. 


\section{Lisa}

Lisa. Kategooriad ja koodid

\begin{tabular}{|c|c|c|}
\hline Kategooria & Koodid & Näited \\
\hline \multirow{4}{*}{$\begin{array}{l}\text { Uus } \\
\text { kirjaoskus }\end{array}$} & Video ja film & Mängu- vm film, telesaade, video \\
\hline & Võõras & $\begin{array}{l}\text { Lausungid, milles tuuakse esile uute tekstide võõrus, } \\
\text { näited õpilaste kasutatud veebitekstidest }\end{array}$ \\
\hline & E-materjalid & E-õpik, e-tund, e-töölehed jm e-materjalid \\
\hline & Multimodaalsus & $\begin{array}{l}\text { Raadiosaated, veebilehed ja -keskkonnad, } \\
\text { sh e-keeleallikad; teatris, muuseumis käimine }\end{array}$ \\
\hline \multirow[t]{6}{*}{$\begin{array}{l}\text { Tekstikeskne } \\
\text { keeleõpetus }\end{array}$} & Takistus & $\begin{array}{l}\text { Õppetööd takistavad tegurid: ajanappus, õpilaste } \\
\text { vähene võimekus, tekstide otsimise keerukus; } \\
\text { soov saada metoodilist tuge ja koolitust }\end{array}$ \\
\hline & Koostöö & $\begin{array}{l}\text { Ainelõiming, teiste õpetajate tegevus ja koostöö } \\
\text { nendega }\end{array}$ \\
\hline & Sõnavara & Sõnavara arendamine tekstide lugemise ajal \\
\hline & ÕS & ÕSi kasutamine lugemise või kirjutamise ajal \\
\hline & Lauseõpetus & $\begin{array}{l}\text { Lauseõpetuses autentsete tekstide kasutamine: } \\
\text { kirjavahemärkide eemaldamine tekstist, lausete } \\
\text { segipaiskamine, vigase teksti analüüs }\end{array}$ \\
\hline & Teised keeled & $\begin{array}{l}\text { Eesti keele ehituse ja grammatika võrdlemine võõrkeele } \\
\text { omaga }\end{array}$ \\
\hline \multirow[t]{6}{*}{$\begin{array}{l}\text { Kirjaoskus- } \\
\text { diskursused }\end{array}$} & Oskused & $\begin{array}{l}\text { Teadmised, tehnilised oskused, traditsioonilised } \\
\text { õigekirja- ja grammatikaharjutused }\end{array}$ \\
\hline & Loovus & $\begin{array}{l}\text { Väärtuskasvatuslikud arutelud, lugemiselamuse } \\
\text { kirjeldamine, õpilasi puudutava teksti käsitlemine tunnis }\end{array}$ \\
\hline & Protsess & Tekst mahukama ülesande osana \\
\hline & Žanr & $\begin{array}{l}\text { Žanri iseärasuste uurimine, eri žanrite võrdlus, } \\
\text { žanriomaste väljendusvahendite esitamine }\end{array}$ \\
\hline & $\begin{array}{l}\text { Sotsiaalne } \\
\text { praktika }\end{array}$ & Teksti ja selle osade kasutamine, küsimustele vastamine \\
\hline & Sotsiopoliitiline & $\begin{array}{l}\text { Teksti toel diskuteerimine, argumenteerimine, oma } \\
\text { seisukoha kujundamine, kriitiline lugemine }\end{array}$ \\
\hline
\end{tabular}




\title{
Developing literacy in Estonian as L1: bridges and gaps
}

\author{
Merilin Aruvee $^{\mathrm{a}}$, Helin Puksand ${ }^{\mathrm{b}}$ \\ ${ }^{a}$ School of Humanities, Tallinn University \\ ${ }^{b}$ Institute of Estonian and General Linguistics, University of Tartu
}

\section{Summary \\ Introduction}

As text work is part of literacy as common core competence, Fisher and Ivey (2005) emphasise the notion that every (subject) teacher is also a language teacher. The terms disciplinary literacy and content area literacy describe this in detail. The former means working with concepts and meanings in learning content, the latter focuses on the nature of texts, vocabulary, textual features and composition, reading skills and strategies (Shanahan \& Shanahan, 2008). In order to build and support content learning, both areas need attention. This is similar to the dual focus in the context of CLIL (Mehisto et al., 2010) where content and language are equally and simultaneously developed.

Technological development has changed the setting of literacy. The deictic nature of new literacies (Leu et al., 2004) is a challenge for schools and teacher training programmes. The term new literacies signifies a set of aspects such as multimodal meaning-making, collaboration, being connected and experimenting with texts etc. (Burnett \& Merchant, 2015; Lankshear \& Knobel, 2018). Educationalists suggest blending the new skills into our everyday actions (Lankshear \& Knobel, 2018). There is no need to demonise new literacies every text is part of meaning-making and is therefore strongly connected with creativity (Knobel, 2017).

The multimodal nature of texts mostly affects literacy teaching in L1 classrooms. Grammar teaching should be more integrated with text work (Myhill, 2018), because grammar is a tool for meaning-making (Halliday, 2005) and always goes hand in hand with (multimodal) reading and writing activities. This view is captured in the term metalinguistic awareness (Carter, 2003; Rättyä, 2013), meaning investigating the texts' linguistic features: grammatical and lexical choices. This is impossible without grammatical metalanguage, which is the responsibility of L1s to teach.

School of Humanities, Tallinn University, Narva mnt 25, 10120 Tallinn, Estonia; merilin.aruvee@tlu.ee 


\section{Research aims, questions and method}

The research problem is to explain how Estonian L1 teachers use texts and build connections with systematic language teaching in order to find ways to teach literacy as a collaboratively shared responsibility.

The aim is to make suggestions for the development possibilities of L1 didactics and Estonian L1 as a school subject and make literacy as the common core. Our first research question focuses on the integration with other subjects; the second question tackles asking how new literacy skills appear in teacher's actions; the last research question investigates how the text-centred approach is practised by interviewees.

An ethnomethodological study (Garfinkel, 1984) was conducted from September 2017 to June 2018 and was divided into 3 stages. This research uses the principle of triangulation (Flick, 2017): theory, data and methods combined to make up the 3 perspectives. In the first stage, one Estonian language teacher (Teele, name changed) was asked to keep a diary describing her text-use in 12 lessons of Estonian L1 and Literature. After that she was interviewed for further comments.

In stage 3, we carried out a focus group interview (3 persons) and an expert group interview (4 persons) with Estonian L1 teachers. To trigger discussions, we used Teele's diary to provide examples of literacy practises.

We analysed the results qualitatively, using programme QDA Miner Lite (Lewis \& Maas, 2007). Firstly, content analysis and guided content analysis was utilised to connect literacy practise examples with Ivaničs literacy discourses (skills, process, creativity, social practice, genre, and socio-political discourse) to see, how new literacies and the text-centred approach appear in teacher's experiences. This was followed by a discourse analysis (Gee, 2003).

\section{Results and discussion}

The responsibility for teaching literacy seems to become more important among both L1 language teachers and their colleagues. Integration between subjects is mainly achieved by content (same topic across subjects), but joint text work is also carried out. Literacy discourses (Ivanič, 2004) clearly outlined skills, social practise, process and sociopolitical discourse. Skills and process combine with each other: the L1 teacher is asked to support writing assignments and to help grade spelling and grammar. In the second case, an important topic or a problem is developed from the perspective of various subjects. In this collaboration the Estonian L1 teacher supports activities with oral discussions and text analysis. The study of $\mathrm{L} 1$ teachers alone isn't sufficient to describe 
how literacy as a common core responsibility has to be shared and whether other subject teachers are ready to provide the co-responsibility (Soodla et al., 2013). This directs us to continue with the research.

There are examples where disciplinary literacy is supported by the L1 teacher - this might indicate the need for CLIL (Mehisto et al., 2010) in Estonian-speaking schools. However, the importance of text and language work will increase in the future when Estonian schools engage more multilingual pupils. We suggest expanding CLILs' dual focus to triple focus of literacy education. The three foci include content area literacy, disciplinary literacy and metalinguistic awareness. Joint text work could begin with new learning material, followed by text input, reading-writing activities in line with subject-specific terminology. The final layer is metalinguistic concepts that the L1 teacher points out, which, according to the study, is a strong side of L1, although not necessarily text-based. This is a perfect compromise where the content area literacy is strengthened along with reading skills and language as a meaningmaking tool becomes more visible.

Compared to social practice and skills discourse, genre discourse is rather modest. We see, that the genre approach (Dean, 2008; Knapp \& Watkins, 2010), could bridge the gap between texts and its metalinguistic layer.

This requires attention in general and subject didactics. Reading strategies, creative writing, and other textual activities could be used as examples in teacher training courses (McArthur, 2012) in order to create the understanding that all teachers are literacy teachers (Fisher \& Ivey, 2005) and that the responsibility for teaching literacy is legally shared (PRÕK, 2011, $\$ 4$ ).

Visual texts are the strongest bridge to new literacies. Short video clips are used for activating students, movies and TV-shows are analysed, discussed and used in process-centred writing assignments. Fictional stories are often compared with their visual remakes, but the visual grammar or metalanguage receives little attention. Visual meaning-making becomes more dominant in today's society, so these skills need more explicit attention. Today's subject teachers cannot do that alone, therefore, new literacy skills need to be blended into the school practice as a whole.

We suggest the following actions to support literacy education and metalinguistic awareness.

- Teacher training programmes should engage more literacy skills, reading strategies and new literacies' practices.

- New literacies need more attention in schools; one solution could be a course that integrates new literacies with different school subjects.

- CLIL as an approach to literacy education could be applied in Estonian schools by focusing on three aspects: content area literacy, disciplinary 
literacy and metalinguistic awareness. This approach needs arrangements by schools, teachers alone cannot guarantee organisation and collaboration among each other.

- Text-centred approach needs many examples and methodical materials, also courses for in-service teachers, especially for teacher trainer practice supervisors.

However when we develop literacy education we should be mindful that Estonian as L1 should not be promoted through other subjects, but should be present in every subject and everywhere as a meaning-making resource and the main goal of Estonian schools.

Keywords: new literacy, text-centred language teaching, metalinguistic awareness, CLIL 